\title{
THE INFLUENCE OF MOTIVATION AND ISLAMIC LEADERSHIP ON LECTURER'S PERFORMANCE AT PRIVATE UNIVERSITIES IN THE PROVINCE OF WEST SULAWESI
}

\author{
Ahmad Tri Sulkarnain*, Basalamah Salim, Gani Ahmad, Lamo Mochtar \\ Faculty of Economy and Business, University of Islam Indonesia, Makassar, Indonesia
}

*E-mail: trisulkarnainahmad@ymail.com

\begin{abstract}
This research is aimed to: (1) analyze the influence of motivation on lecturer's performance at private universities in the Province of West Sulawesi; (2) to analyze the influence of Islamic leadership on the lecturer's performance at private universities in the Province of West Sulawesi. This study employed primary and secondary data involving 173 lecturers as the sample of total lecturers at the private universities in the Province of West Sulawesi. The lecturers listed in the database of General Directorate of Higher Education are 434 people. The survey was conducted from September to December 2016, and the data were analyzed using Strucural Equation Modeling (SEM) program. The results of this study show that: (1) motivation has positive but not significant influence on the performance of the lecturers; and (2) Islamic leadership has significant and positive impact on the performance of the lecturers.
\end{abstract}

\section{KEY WORDS}

Motivation, Islamic leadership, performance.

For higher education institution, one of the most crucial parties who play strategic role in improving the progress and quality of the institution is the performance of the lecturers. In line with the statement, Tung Yao Khoe in Achmad Sanusi and Uwes Sanusi in Muhardi (2004) states that "lecturers are the key factor of success on efforts to improve the quality of education services". The same opinion was expressed by Abdurrahman and S. Marten Yogaswara in Muhardi (2004:34) stating that "the value of educational success is highly dependent on the quality of teaching. Lecturers are the people who are very instrumental in teaching and learning process."

Lecturers should have some qualifications that are very important for the implementation of their profession, given the profession as lecturers is different with other professions. In addition, this profession requires special sciences and expertise to convey their knowledge to the students. Motivated and competent lecturers with good quality are able to facilitate the delivery of sciences and technology to the students so that teh materials can be accepted and developed in accordance with the student's ability to study based on their major. In terms of commitment, lecturers should be committeed to attending regurlarly at work, as well as having a sense of responsibility for the education they teach to the students.

In improving the performance of the lecturers, carrying out the duties and responsibilities as a lecturer and educator, in particular the implementation of the three basic duties of higher education is largely determined by their motivation to work.

Motivation is very influential on the performance of a lecturer. In general definition, motivation is such encouragement that arises in a person either consciously or unconsciously to act with a certain purpose while the desire is craving something (inclination or impulse) with strong heart to do anything either good or bad. The concept of motivation in the Islamic perspective has wider scope because every action should be committed as an effect of motivation must be based on good intentions, as well as the purpose of the action or activity should meet the needs of both physical (material) and spiritual in order to achieve happiness in this world and also the salvation hereafter.

Motivation to pursue achievement is an encouragement to the characteristics of a person doing a good job and high performance. The need for high achievement is an encouragement that may arise in a person's attempt to achieve the targets set, working hard 
to achieve success and having the desire to do something better than before.

Motivation at private colleges, however, seems not yet provided the encouragement for the lecturers to perform well.

The core of motivation is the existence of desire to achieve something related to the needs of human life. One of the prominent theories is the motivation theory proposed by Abraham Maslow called Maslow's Hierarchy of Needs that divides the needs of over five levels, namely: (1) physiological needs, (2) safety and security needs, (3) social needs, (4) esteem needs, and (5) self-actualization needs.

According to Hasibuan (2007), motivation comes from the Latin word movere which means encouragement or something as leverage. In professional context, motivation focuses on how the power and potential direct the subordinates to cooperate productively managing to reach and realize the objectives that have been determined optimally. The motive is a simultaneous desire and leverage to the willingness to work; the motif of someone has different purpose.

Kartini Kartono through her book "Leaders and Leadership" defines a leader as a person who has the skills and strengths, in particular expertise and skills in one field, so he or she is able to influence others together to perform certain activities, in order to achieve one or multiple objectives. It can be concluded that as a leader who has one or more advantages as predisposition (innate talent), and this becomes the needs in one situation, so he or she has the power and authority to direct and lead his subordinates. He may also gain recognition and support from the subordinates to move towards specific destination.

In the perspective of Islam, leadership is considered as a group or collective responsibility. Therefore, Islam takes the issue of leadership in an attempt to maintain the existence of the group that as an organization should have objectives. Furthermore, the position of leadership position in the organization will not only strengthen the activities of the members, but also will meet and ensure the individual and collective purposes that exist within the organization.

After the death of Prophet Muhammad, based on historical facts in Islam, Muslim communities were divided as the debate about leadership in Islam, especially regarding the process of selection of leaders in Islam-who should be entitled to the leadership in Islam. Thus, the definition and meaning of leadership and authority should be implemented with the principles outlined Quran. Men as the leader should have the ability to influence other people to achieve the goal.

One Prophetic leadership is applied and followed by the Caliph Abu Bakr Shidiq to always maintain his dignity, Umar Ibn Khattab with the firmness, honesty and justice, Ustman bin Affan with the generosity, and Ali Ibn Abi Talib with visions and courage.

Moh. Ali Shahab (2010) through his the research found that the Islamic leadership is positively influential positive and significant to the employee's job satisfaction at Maal Wa Tamwil in the Province of Central Java. Furthermore, the Islamic leadership has significant positive effect on the job performance of the employees. Islamic job satisfaction also has positive and significant effect on the performance of the employees. Based on quantitative and qualitative analyses, it can be structured in an integrated way that leadership, Islamic job satisfaction and Islamic performance have positive impact on the organization. A leader should always be fair and become the role model or example for the subordinates; in other words, leadership is the ability to realize all the will of Allah.

The leadership of lecturers can be identified from the academic rank they have as to have leadership positions in the higher education, academic positions become one of the basic considerations to appoint the officials at universities.

The definition of performance by Payaman Simanjuntak (2005) is suggested as the level of achievement of results as the implementation of certain tasks. The company's performance is the level of achievement in order to realize the goals of company. Performance management is the overall activities undertaken to improve the performance of the companies or organizations, including the performance of each individual and group work at the company.

In essence, the performance is the result of work achieved by a person in performing 
their duties in accordance with the standards and criteria set for the tasks. Performance is a function of motivation and capabilities.

According to Steers (1991), there are three basic factors that may affect the performance:

1. Capability, personality, and willingness to work,

2. The certainty and reception of the tasks or workloads assigned to the individual, and

3. The level of work motivation.

According Cash and Fisher (1987) performance is also considered a result, which means that anything that has been produced by the individual worker. The results are influenced by the performance of the organization whose components consist of organizational development compensation structure, policies and procedures.

Based on some opinions about the work performance can be concluded as the notion containing work achievement by someone. In short, job performance could be said as the reflection of the results achieved by an individual or group. There is a close relationship among individual performance, institutional performance, and corporate performance. In other words, if the employee's performance (individual performance) is good, it is most likely the performance of the company is good as well.

From the data and phenomena discussed above, to determine the relationship between competence, motivation, and Islamic leadership on the job satisfaction and performance lecturer at private universities in West Sulawesi, the research would be in the area of the influence of motivation and Islamic leadership on the performance of the lecturers at private universities in the Province of West Sulawesi.

\section{LITERARY REVIEW}

Work motivation is processes in which human beings are encouraged to perform the activity as the results of the needs that should be met; in line with the idea that employees will be able to carry out certain tasks faithfully when they are assigned particular encouragement in accordance with their needs.

According to Stoners (1992), motivation is the condition of human psyche and the mental attitudes that may energize and galvanize actions, directing or channelling behaviors towards achieving satisfying desires or reducing the imbalance. Handoko (2003) defines motivation as a state in the person of someone who drives the individual desire to undertake certain activities to achieve the objectives of the activities.

According Sterr (1991), the motivation has the power that an individual tends to engage in activities which leads to certain target in relation to job satisfaction, and also the feeling of more pleasure or willingness to work in order to achieve the goals. To achieve effectiveness of motivation, it is necessary motivational theories from several experts as the reference to discuss motivation. The theories of motivation as listed by Robbins (2008) are as follows:

1. Hierarchy of Needs Theory:

Hierarchy of Needs theory is the most popular theory of motivation formulated by Abraham Maslow. The hypothesis says that inside every human being, there are five levels of needs, as follows:

a. Physiological needs. These are human needs that are physical. Such as: hunger, thirst, protection (clothing and housing), sex, and other physical needs.

b. Security needs. These are the human needs that arise after the physical needs have been met, namely safety and protection against physical and emotional damages.

c. Social Needs. These are human needs that arise because of the social interactions between one person with others, and between individual and groups. These needs include compassion, a sense of belonging, a sense of receiving and friendship.

d. Recognition Needs. These are human needs that are more related to personal interests or ego. These needs are likely related to internal factors including awards such as, self-esteem, autonomy, and achievement, as well as external factors such awards, social status, recognition, and attention.

e. Embodiment or Self-actualization Needs. These are human needs for someone to be 
the appropriate human skills, namely the growth, achievement of certain potential, and self-fulfillment.

2. Theories $X$ and $Y$ :

The theory of motivation by Douglas McGregor has developed two real views about humans, namely: the first is essentially negative called Theory $X$ and the other is basically positive called Theory Y. McGregor concludes that the views of a leader of human nature should be based on certain assumptions groups that they tend to form their behavior towards the employees based on these assumptions.

According to Theory $\mathrm{X}$, there are four assumptions belong to leaders as follows:

a. Employees basically do not like the job and as much as possible try to avoid it.

b. Because employees do not like the job, they should be coerced, controlled, or threatened with punishment to achieve the objectives.

c. Employees will avoid responsibilities and seek formal command whenever possible.

d. Most employees put security above all other factors associated with jobs and show little ambition.

e. In contrary to the negative assumptions above, McGregor makes four positive assumptions called as Theory $\mathrm{Y}$ as follows:

f. Employees consider their job as something fun just as the rest or play.

g. Employees will be trained to control themselves and emotions to achieve various objectives.

h. Employees will be willing to learn to accept and even learn to be more responsible.

i. Employees are able to make innovative decisions circulated to the entire population, not just for those who occupy the management positions.

The conclusion of this theory is that Theory $X$ assumes that needs lower level is trying to dominate the individual, while Theory $Y$ assumes that the needs of a higher level dominates individual. McGregor himself believes that the assumptions of Theory $Y$ are more valid than Theory $\mathrm{X}$.

Subject of Islamic leadership has already existed and been evolving, particularly after the death of Prophet Muhammad. The discourse related to the leadership has arisen because there is no longer prophecy after the death of Prophet Muhammad, as stated in Quran that this prophecy is final and cannot be amended anymore, meaning that Prophet Muhammad is the last messenger and the finisher of the previous treaties.

The basic characteristic of the leadership by Prophet Muhammad who became exemplary all Muslims by nature lie in his personality. Prophet Muhammad is a human being with all of the attributes of humanity, and as a human being, he was born with clear offsprings as normal person; he played, learnt, worked, got married and had children. He also felt what was perceived by other human beings in general, such as hope and fear, poor and rich, airy and hard, aloof and society. As a leader, he was like other; he stood together and sat together before the law, gained the victory and power, and experienced defeat as well as sadness.

In terms of intelligence (Arab: fathonah), Prophet Muhammad has obtained the integrity of self-knowledge and maturity with unwavering principles and learned from experiences. Muhammad is known to have high integrity, be committed to what is said and being able to build a strong team such as in military expeditions. He also has a high ability to assume the prophecy with all extraordinary risks and courage. He is also smart in mastering changes as shown through his decision of migrating to Medina from Mecca, and it was initiated by Prophet Muhammad; this migration is believed as the influential to the maps and directions modern global civilization. He is believed to also have initiation to peacefully conquer Mecca, and it was the proof of the success of the leadership of Muhammad. He also often invited his companions for the opinions in relation to strategic issues, for example in determining the strategy of war and social affairs.

Furthermore Antonio (2008) presents three holistic leadership traits as shown by Prophet Muhammad, namely the ability to develop leadership in various fields and these are accepted, leadership which is recognized more than 1.3 billion people and proven; and the leadership has been proven since The $15^{\text {th }}$ Century ago, and it is still relevant and applied to 
this day.

The process of crystallization of the characteristics of Prophet Muhammad was as a leader who is generous, patient, loving, forgiving, promoting human values, faithful and sincere, and devoted to God Almighty (Allah). These leadership traits give real picture, as loud, assertive, and straightforward characteristics as the representation of his desire to humanize the humans before the God.

Exemplary by Prophet Muhammad is reflected in his characteristics consisting of four main properties that truthful (Arab: siddiq), trustworthy (amanah), smart (fathonah) and transparent to deliver (tabligh) (Waffa, 2012), and these are the core leadership characteristics of the Prophet Muhammad.

\section{CONCEPTUAL FRAMEWORK OF RESEARCH}

This conceptual framework describes the relationship among the variables of this research. The relationship among the variables of this research is based on the theory of motivation, leadership, and performance. Based on the relationship among variables based on relevant theories and previous research, the conceptual framework of the study was formulated.

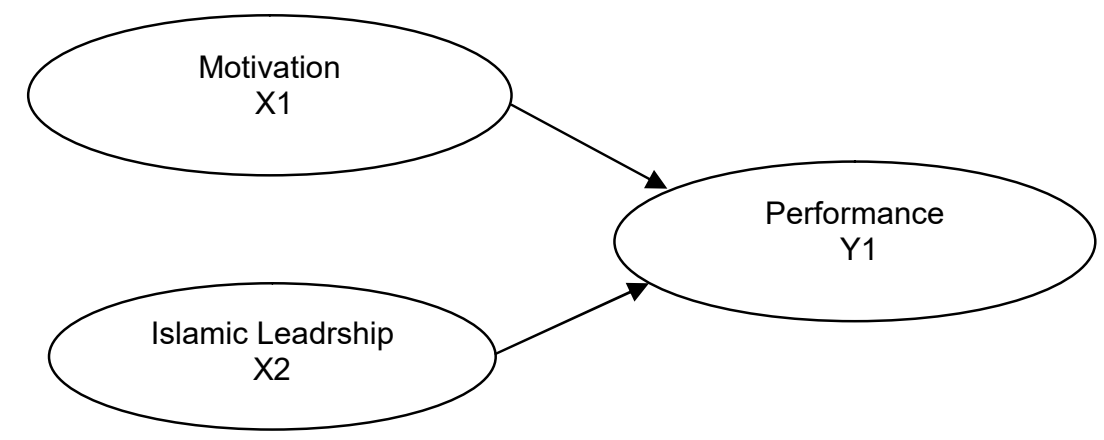

Figure 1 - Conceptual Framework

Research Hypotheses. Referring to Handoko (2003) defines motivation as a state in the person who encourages the desire of individuals to undertake certain activities to achieve the objectives. The Hierarchy of Needs theory of motivation is the most prominent by Abraham Maslow. The hypothesis says there are five levels of needs inside every human being.

In relation to the previous studies, the researchers who examined the relationship between motivation and the performance were including Suseno Pradja (2010), Kwelju Jonah (2009), Hidayat Pontoh (2012), Fahri Ahmad (2012):

$\mathrm{H} 1$ : Motivation is positively and significantly influential on the performance of lecturers.

Characteristics of Islamic leadership has been shown by referring to the leadership of Prophet Muhammad based on his personality which, according to Al-Maliky (2007: 252) characteristics which are good morality (Arab: karimah), modesty (qonaah) and consistent (istiqomah).

Islamic leadership may affect the job satisfaction and performance which is supported by a group of researchers from Ohio University, United States (in Yukl, 1994) and Moh. Ali Shahab (2010). Based on the theoretical and research study, the research framework of human resources can be simplified or formulated to explain the influence of motivation and Islamic leadership on the performance of the lecturers at private universities in the Province of West Sulawesi. the lecturers.

$\mathrm{H} 2$ : Islamic leadership is positively and significantly influential on to the performance of

Operational Definitions:

Motivation Variable $(X 1)$. In this context, motivation is a strong desire that comes from 
within of the lecturers to carry out activities until the implementation or three basic duties of higher education that have been the bases for the academic schedule, and the indicators are as follows:

1. Process of being happy at work;

2. Process of willingness to work;

3. Process of sense of belonging;

4. Process of achievement;

5. Process of creative desires.

Islamic Leadership Variable (X2). Islamic leadership is attitudes and behavior that correspond to the characteristics of Islamic leadership as performed by the lecturers and has the following indicators:

1. Truthful (shiddiq);

2. Trustworthy (amanah);

3. Smart (fatonah);

4. Transparent to deliver (tabligh).

Performance Variable (Y1). Performance in this context is the performance of the lecturers as the activities or the abilities of the lecturers in implementing academic programs related to the duties of three basic duties of higher education, which has the following indicators:

1. Quality of work

2. Capability

3. Initiative

4. Communication

5. Punctuation

\section{METHODS OF RESEARCH}

The research was conducted at private universities across the Province of West Sulawesi. The duration of this study was over three months (September to December 2016). The data in this study were analyzed through SEM (Structural Equation Model) by using AMOS (Ghozali, 2008: 18), and the data analysis was conducted through quantitative analysis approach.

\section{FINDINGS AND DISCUSSION}

Hypothesis 1: There is positive and significant influence of the motivation of the performance of the lecturers at private universities in the Province of West Sulawesi.

The results of this study support the previous study conducted by Eva Kris Diana Devi (2009), Kwelju Jonah (2009), and Mamik (2008). In addition, this study is empirically to support the theory by Robbins (2003), that to identify the behaviors of individual or an organization, internal environment or external causes should be understood and examined.

The appproach to nature and the environment to work motivation in the research carried out by Zainie Nur Hassan Abd Hamid and Narehan (2015) found that the working environment has weak relationship with teh performance of the employees. Through the improved work environment, however, the employees will be more motivated to work harder, which is as the realization of employee's satisfaction. As the result, ultimately they will improve their performance. Teh condition of work environment, the nature, remuneration policy, the type of work assigned and supervision of a leader are to include as the element of extrinsic motivation (hiegiene factor in Herzberg's theory). If the elements have not been inadequate, they may cause dissatisfaction among teh employees. If the condition of the elements are accommodated by the management, they will eliminate dissatisfaction; this condition even improves the satisfaction of the employees.

Hypothesis 2: There is positive and significant influence of Islamic leadership on the performance of the lecturers at private universities in the Province of West Sulawesi.

Islamic leadership is positively and significantly influential on the performance of the 
lecturers. The findings of this study are in line with the results of previous studies conducted by Moh.Ali Shahab (2010) that the Islamic leadership significantly influences the performance of the employees.

In addition, according to Rafik I. Beekun (2012) in its publication entitled Charactercentered leadership: Muhammad $(p)$ as an ethical role model for CEOs, he said that the leadership of Prophet Muhammad stems from the character (morality) The model of leadership by Prophet Muhammad has been applied to a number of previous social and religious area. Islamic leadership based on morality is the first attempt to explain the Quranic values on the aspects of the role model (khuluqin azeem). As this aspect is fully elaborated, it is likely to offer an alternative role model based on the virtues and implemented into transactional leadership model and also transformational leadership approaches upon relevant relativistic virtues. Some publications and studies have revealed that the transactional and transformational leadership has been proven to affect the employee's performance. The same thing was stated by Yasir Majeed, Zulqarnain Khalid and Mohammad Aslam Khan (2011) in the Islamic study entitled the impact on organizational leadership Objectives. They found that the Islamic leadership is performed through consultation (Arab: al shura), justice, trust, and trustworthy (al shidq). The research was conducted in Malaysia, and it found that the factors forming the Islamic leadership have influence on the employee's performance. The results are consistent with the findings of research conducted in other countries, especially in Malaysia.

Limitation of the Research. The research area is very limited, only in the Province of West Sulawesi. The research should have covered the entire regional coordination of private universities in Sulawesi. As conducted in wider coverage, the generalization can be done through more comprehensive and more accurate results.

\section{CONCLUSION}

Motivation has a positive and significant impact on the job satisfaction of the lecturers. In relation to the performance of the lecturers at the private universities in the Province of West Sulawesi, however, motivation has positive effect but not significant. This means the motivation of the lecturers at the private universities in West Sulawesi is still low, so the passion to achieve satisfactory performance is low as well. However, as the motivation has positive correlation with the performance, if the motivation of the lecturers would be improved, their performance will be increasing as well.

Islamic leadership has positive and significant impact on the job satisfaction of the lecturers. The implementation of Islamic leadership should be maintained and even increased in the future.

\section{SUGGESTIONS}

It is important to maintain the motivation to work of the lecturers at the private universities in the Province of West Sulawesi, especially the intrinsic motivation including the initiative to achieve and desire to carry out the tasks being appointed. By enhancing the intrinsic motivation, the teachers will be motivated to improve their performance.

It is suggested that the application of the Islamic leadership intensively in the future because it affects the job satisfaction and performance of the lecturers.

\section{REFERENCES}

1. Amstrong Michael dan Helen Murlis, 2003, Reward manajement, Jakarta PT. Buana IImu Populer.

2. Cash, Fisher, Cynthia D., Scoenfeldt, Lyle F., and show, James B,. 1987, Human Resources Management, Boston: Houghtonn Miffin.

3. Handolo, Hani T, 2003, Manajemen Personalia dan Sumber Daya Manusia, Edisi Kedua, BPFE, Yogyakarta. 
4. Hasibuan, malayu S.P, 2007, Manajemen Sumber Daya Manusia, Edisi Revisi, PT. Bumi Aksara, Jakarta.

5. Hutapea Parulian dan Thoha Nurianna, 2008, Kompetensi Plus, Teori, Desain, Kasus, dan Penerapan Untuk HR dan organisasi yang Dinamis, PT. Gramedia, Jakarta.

6. Koontz, Harold, Cyril O'Donnel, dan Heinz Weihrich, 1989, Management, 8 Th ed. New York: McGraw-Hili-Inc.

7. Mantra, Ida Bagus, dan Kasto, 1985, Penentuan Sampel, Metode Penelitian Survei Editor Masri Singarium dan Sofyan Effendy, Edisi revisi, Penerbit LP3ES, Jakarta.

8. Nawawi H, 2000, Perencanaan Sumber Daya Manusia, Yogyakarta: Gajah Mada University.

9. Panggabean Mutiara S, 2002, Manajemen Sumber Daya Manusia, Bogor, Galia Indonesia.

10. Rivai, Veithzal, dan Ella Janvaun sagala, 2009, Manajemen Sumber Daya Manusia Untuk Perusahaan, Dari Teori ke Praktek, Edisi Kedua, PT. Raja Grafindo Persada, Jakarta.

11. Simamora, Henry, 2006, Manajemen Sumber Daya Manusia, Cetakan Kedua, STIE YPKN, Yogyakarta.

12. Steers. M. Richard and Porter M., 1991, Introduktion to Organisational Behavior, 4TH Edition. Harper Collins Publisher New Jersey.

13. Stoneers, A.F. James, and Edward R Freeman, 1992.Management, Edisi Terjemahan Penerbit Intermedia, Jakarta.

14. Swasta, Bambang, 2003. Pengembangan SDM (Pengaruhnya Terhadap Kinerja dan Imbalan). Edisi Pertama, Penerbit Bayu Media, Malang.

15. Timpe, A. Dale, 2008, Memotivasi Pegawai, Cetakan Keempat, Penerbit: PT. Gramedia Asrti Media, Jakarta.

16. Achmad Tjahjono. 1996. "Kompensasi Intensif Sebagai Alat Untuk MemotivasiAnggota Organisasi Dalam Upaya Mencapai Tujuan Organisasi.” KajianBisnis, No. 7, pp.34-41

17. Arrizal. 1999. "Motivasi Kerja Dapat Dibangkitkan Dengan Pemberian TunjanganPegawai." Kajian Bisnis, No. 17, pp.23-27

18. Dessler, Gary. 1997. Manajemen Sumber Daya Manusia Edisi Bahasa IndonesiaJilid 2.Jakarta: Prenhallindo.

19. Dessler, Gary. 2000. Human Resource Management 8th Edition. New Jersey:PrenticeHall, Inc.

20. Gomes, Faustino Cardoso. 2003. Manajemen Sumber Daya Manusia. Jogjakarta:Andi Offset.

21. Guritno, Bambang dan Waridin. 2005. "Pengaruh Persepsi Karyawan MengenaiPerilaku Kepemimpinan, Kepuasan Kerja dan Motivasi TerhadapKinerja.” JRBI, Vol.1 No. 1, pp.63-74

22. Hani Handoko. 1993. Manajemen Personalia dan Sumberdaya Manusia Edisi 2.Yogyakarta: BPFE.

23. Hani Handoko. 2002. Manajemen Personalia dan Sumberdaya Manusia.

24. Yogyakarta: BPFE.Hariandja, Marihot Tua Efendi. 2002. Manajemen Sumber Daya Manusia.Jakarta: Grasindo.

25. Haryono. 2009. "Pengaruh Karakteristik Pekerjaan Dan Kompensasi TerhadapKinerja Pegawai Dengan Mediasi Motivasi Kerja (Studi Pada PegawaiBadan Pelaksana Penyuluhan Pertanian, Perikanan dan KehutananKabupaten Batang." Tesis Tidak Dipublikasikan, Program PascasarjanaMagister Manajemen, Universitas Stikubank Semarang.

26. Hasibuan, Malayu S.P. 2002. Manajemen Sumber Daya Manusia Edisi Revisi.Jakarta: Bumi Aksara.

27. Herman, Sofyandi. 2008. Manajemen Sumber Daya Manusia. Yogyakarta: Grahallmu.Heru Kurnianto. 2009. "Penilaian Kinerja Karyawan Berdasarkan Definisi, Tujuan, dan Manfaat"http://jurnal-sdm.blogspot.com/2009/04/penilaian-kinerja-karyawandefinisi.html, Diakses tanggal 10 Maret 2010.95

28. Imam Gozali. 2005. Aplikasi Analisis Multivariate dengan Program SPSS Edisi 
3.Semarang: Badan Penerbit Universitas Diponegoro.

29. Lies Indriyani. 2009. "Analisis Pengaruh Kompensasi dan Lingkungan KerjaTerhadap Produktivitas Kerja Perawat Dengan Kepuasan Kerja SebagaiVariabel Mediasi." Jurnal Ekonomi - Manajemen - Akuntansi, No. 26,Th. XVI, pp. 117-127

30. M, Manulang. 1984. Management Personalia. Jakarta: Ghalia Indonesia.

31. Mathis, Jackson. 2000. Manajemen Sumber Daya Manusia. Jakarta: SalembaEmpat.

32. Mahmudi, 2005.Manajemen Kinerja Sektor Publik. Jogjakarta: UPP AMPYKPN.

33. Masrukin dan Waridin. 2006. "Pengaruh Motivasi Kerja, Kepuasan Kerja, BudayaOrganisasi dan Kepemimpinan terhadap Kinerja Pegawai," JurnalEkonomi dan Bisnis. Vol. 7 (2), Juni: 197-209

34. McClellan, David. 2008. "Teori Motivasi McClellan \& Teori Dua FaktorHezberg"

35. Nawawi, H. 2001. Manajemen Sumber Daya Manusia. Yogyakarta: Gadjah MadaUniversity Press.

36. Panggabn, Mutiara S. 2002. Manajemen Sumber Daya Manusia. Jakarta: Ghallialndonesia.

37. Rita Swietenia. 2009. "Analisis Pengaruh Kepemimpinan, Kompensasi danKarakteristik Pekerjaan Terhadap Disiplin Kerja Serta ImplikasinyaTerhadap Kinerja Pegawai (Studi Pada Kantor Pertanahan KotaSemarang)." Jurnal Ekonomi - Manajemen - Akuntansi, No. 26, Th.XVI, pp. 96-116

38. Robbins, Stephen P. 2007. Perilaku Organisasi. PT Indeks.

39. Santoso, S. 2004. Buku Latihan SPSS Statistik Multivariat.Jakarta: Elex MediaKomputindo.

40. Sastrohadiwiryo, Bejo Siswanto. 2003. Manajemen Tenaga Kerja IndonesiaPendekatan Administrative dan Operasional. Jakarta: Bumi Aksara.

41. Simamora, Henry. 2004. Manajemen Sumber Daya Manusia. Yogyakarta: SIEYKPN.96

42. Sopiah. 2008. Perilaku Organisasional. Yogyakarta: Andi Offset.

43. Sugiyono. 2002. Statistika untuk Penelitian. Bandung: CV Alfabeta.

44. Suyadi Prawirosentono. 1999. Kebijakan Kinerja Karyawan. Yogyakarta: BPFE.

45. Sri Wuryanti. 2009. "Pengaruh Kompensasi dan Lingkungan Kerja TerhadapPrestasi Kerja Dengan Motivasi Sebagai Mediasi (Studi Pada SatuanPolisi Pamong Praja Provinsi Jawa Tengah)." Tesis TidakDipublikasikan, Program Pascasarjana, Universitas Stikubank Semarang.

46. Triyono Nugroho. 2009. "Pengaruh Kompensasi dan Kepemimpinan" 